\title{
PENGEMBANGAN HIGHER ORDER THINKING SKILLS DALAM PEMBELAJARAN MATEMATIKA DI SMP
}

\author{
Rafiq Badjeber ${ }^{1}$, Jayanti Putri Purwaningrum ${ }^{2}$ \\ ${ }^{1}$ Program Studi Pendidikan Matematika, FKIP, Universitas Alkhairaat \\ rafiqbadjeber@yahoo.co.id \\ ${ }^{1}$ Program Studi Pendidikan Matematika, FKIP, Universitas Muria Kudus \\ jayanti.putri@umk.ac.id
}

\begin{abstract}
ABSTRAK
Pembelajaran matematika abad 21 menekankan pentingnya pengembangan kemampuan kreativitas (creativity), kemampuan berfikir kritis (critical thinking), kerja sama (collaboration) dan kemampuan komunikasi (communication). Matematika merupakan suatu ilmu yang bertujuan melatih peserta didik untuk berpikir kritis, sistematis, logis, analitis, dan kreatif serta memiliki kemauan kerja yang efektif yang merupakan suatu keterampilan berpikir tingkat tinggi atau Higher Order Thinking Skills. Pengembangan Higher Order Thinking Skills (HOTS) dalam pembelajaran merupakan salah satu wujud pengimplementasian kurikulum 2013, sehingga kegiatan pembelajaran maupun evaluasi yang dilakukan hendaknya berorientasi pada HOTS. HOTS khususnya dalam matematika lahir dari sebuah proses yang berkesinambungan dan tidak hanya berorientasi pada hasil. Dibutuhkan suatu proses yang kontinu dan konsisten untuk melatih dan membiasakan para siswa. Hal ini harus dimulai sejak awal kegiatan pembelajaran berlangsung hingga selesai bahkan proses refleksi dan evaluasi. Guru harus dapat memfasilitasi siswa untuk menjadi pemikir dan pemecah masalah yang baik.
\end{abstract}

Kata Kunci : Higher Order Thinking Skills, Pembelajaran Matematika.

\begin{abstract}
21 st century mathematical learning emphasizes the importance of developing creativity, critical thinking, cooperation and communication skills. The aims of Mathematics are to trained students to think critically, systematically, logically, analytically, and creatively and have an effective willingness to work which is a Higher Order Thinking Skills. The development of Higher Order Thinking Skills (HOTS) in learning is one manifestation of the implementation of the 2013 curriculum, so that learning and evaluation activities carried out should be oriented to HOTS. HOTS especially in mathematics was born from a continuous process and not only results oriented. A continuous and consistent process is needed to train and familiarize students. This should start from the beginning of the learning activities to take place until the completion of even the process of reflection and evaluation. Teachers must be able to facilitate students to become good thinkers and problem solvers.
\end{abstract}

Keywords : Higher Order Thinking Skills, Mathematical Learning

\section{PENDAHULUAN}

Setiap individu manusia merupakan makhluk yang dituntut untuk terus belajar sepanjang hayat. Belajar merupakan kegiatan setiap manusia dengan tujuan untuk melakukan perubahan diri menjadi lebih baik dalam hal pengetahuan, keterampilan, atau hal-hal lainnya. Proses menjadikan seseorang untuk belajar dapat difasilitasi melalui kegiatan pembelajaran.

Di abad 21 ini perkembangan ilmu pengetahuan dan teknologi semakin maju dengan pesatnya. Kegiatan pembelajaran yang dikembangkan juga harus terus berinovasi demi terwujudnya kualitas pembelajaran yang baik serta relevan dengan 
kondisi saat ini. Pembelajaran matematika merupakan salah satu yang juga harus selalu melakukan inovasi dan pembaharuan karena matematika merupakan suatu ilmu dasar yang banyak berperan dalam kehidupan sehari-hari maupun dalam pengembangan ilmu dan teknologi. Matematika merupakan suatu cabang ilmu yang perlu untuk dipelajari oleh setiap individu khususnya para peserta didik di sekolah karena merupakan mata pelajaran yang dipelajari di semua tingkatan pendidikan mulai SD, SMP hingga SMA. Pembelajaran matematika abad 21 menekankan pentingnya pengembangan pada empat kemampuan yang meliputi kreativitas (creativity), kemampuan berfikir kritis (critical thinking), kerja sama (collaboration) dan kemampuan komunikasi (communication). Kemampuan-kemampuan tersebut harus diintegrasikan dan diimplementasikan dalam pembelajaran matematika di sekolah. Seorang guru sebagai perantara penyampai informasi kepada siswa tentu memiliki peran penting dalam mensukseskan hal tersebut.

Permendiknas Nomor 22 tahun 2006 menyebutkan bahwa setiap jenjang pendidikan diberikan mata pelajaran matematika dengan tujuan agar siswa memiliki kemampuan: 1) memahami konsep matematika, menjelaskan keterkaitan antarkonsep dan mengaplikasikan konsep secara luwes, akurat, efisien dan tepat dalam pemecahan masalah; 2) menggunakan penalaran pada pola dan sifat, melakukan manipulasi matematika dalam membuat generalisasi, menyusun bukti, atau menjelaskan gagasan dan pernyataan matematika; 3) memecahkan masalah yang meliputi kemampuan memahami masalah, merancang model matematika, menyelesaikan model dan menafsirkan solusi yang diperoleh; 4) mengkomunikasikan gagasan dengan simbol, tabel, diagram, atau media lain untuk memperjelas keadaan atau masalah, dan 5) memiliki sikap menghargai kegunaan matematika dalam kehidupan, yaitu memiliki rasa ingin tahu, perhatian, dan minat dalam mempelajari matematika, serta sikap ulet dan percaya diri dalam pemecahan masalah. Berdasarkan uraian tersebut, matematika merupakan suatu ilmu yang bertujuan melatih peserta didik untuk berpikir kritis, sistematis, logis, analitis, dan kreatif serta memiliki kemauan kerja yang efektif. Kemampuan berpikir kritis, logis, reflektif, metakognitif dan kreatif merupakan suatu keterampilan berpikir tingkat tinggi atau Higher Order Thinking Skills (King, Goodson \& Rohani, 2012). Akan tetapi, kenyataannya pengembangan kemampuan berpikir tingkat tinggi matematis saat ini belum optimal.

Penelitian kualitatif Purwaningrum (2012) pada siswa kelas XI salah satu SMA di Kabupaten Pekalongan yang membagi siswa menjadi tiga kelompok yaitu kelompok siswa kreatif, kurang kreatif dan tidak kreatif, menunjukkan bahwa pada pembelajaran pengajuan masalah, siswa pada kategori kurang kreatif dan tidak kreatif mengalami kesulitan pada indikator fleksibilitas dan kebaruan. Siswa pada kelompok kategori tersebut membutuhkan waktu yang lama untuk memunculkan ide. Ketika menemukan ide, mereka juga tidak yakin terhadap ide soal pengajuan masalah sekaligus penyelesaian masalahnya. Hal ini didukung oleh temuan Purbaningrum (2017) bahwa kemampuan berpikir tingkat tinggi siswa ditinjau dari gaya belajar visual, auditori dan kinestetik semuanya tergolong rendah.

Pengembangan Higher Order Thinking Skills (HOTS) dalam pembelajaran merupakan salah satu wujud pengimplementasian kurikulum 2013, sehingga kegiatan pembelajaran maupun evaluasi yang dilakukan hendaknya berorientasi pada HOTS. Salah satu upaya kongkrit pemerintah untuk mewujudkan hal tersebut diantaranya melalui adanya peningkatan persentase soal-soal kategori HOTS khususnya dalam mata pelajaran matematika yang disisipkan dalam soal Ujian Nasional setiap tahunnya. Namun, tingkat capaian peserta didik dalam UN khususnya bidang matematika masih cukup rendah bahkan cenderung mengalami penurunan setiap tahunnya. Penurunan terparah terjadi di tingkat SMP/MTs. Berdasarkan konferensi pers UN 2018 jenjang SMP rata-rata nilai UN matematika tahun 2016 adalah 61,33, tahun 2017 turun menjadi 52,69 dan pada tahun 2018 merosot tajam menjadi 31,38 (Kemdikbud, 2018). Mendikbud menyatakan bahwa terjadinya penurunan skor UN 2018 
yang cukup drastis diantaranya disebabkan oleh adanya peningkatan soal HOTS mencapai $10 \%$ sampai dengan $15 \%$. Selain itu dalam skala yang lebih luas, berdasarkan hasil PISA yang dilakukan setiap tiga tahun sekali sejak tahun 2000 hingga tahun 2015 terhadap siswa dibawah 15 tahun, diperoleh data bahwa siswa Indonesia selalu menempati posisi 65 besar atau dapat dikatakan terendah dalam PISA (Kemdikbud, 2016). Walaupun hasil PISA Indonesia pada tahun 2015 mengalami kenaikan, namun kenaikanannya belum signifikan yakni masih menempati urutan 63 dari 70 peserta yang berpartisipasi (OECD, 2016). Hal ini sejalan dengan capaian peserta didik kelas 8 di Indonesia dalam hasil studi TIMMS 2011 (Mullis, et al, 2012) yang berada pada kategori rendah. Rendahnya hasil PISA dan TIMMS siswa Indonesia ini, disebabkan oleh lemahnya kemampuan siswa dalam pemecahan masalah soal non-routine atau level tinggi (HOTS). Oleh karena itu, diperlukan suatu perhatian yang mendalam terhadap pengembangan Higher Order Thinking Skill (HOTS) yang dimiliki oleh siswa dalam bidang matematika khususnya di jenjang SMP.

\section{PEMBAHASAN}

Masalah matematika diberikan kepada siswa untuk melatih diri dalam menggunakan kemampuan berpikir, serta untuk mengetahui posisi tingkat berpikir yang dimiliki masingmasing siswa. Berdasarkan tingkatan proses, berpikir dibagi menjadi dua tingkat yaitu berpikir tingkat rendah (Lower Order Thinking) dan berpikir tingkat tinggi (Higher Order Thinking). Kemampuan berpikir merupakan kemampuan memproses informasi secara mental atau kognitif yang dimulai dari tingkat rendah hingga tingkat tinggi. Setiap siswa diarahkan untuk memiliki kemampuan berpikir hingga tingkat tertinggi sehingga berpikir tingkat tinggi (Higher Order Thinking) merupakan tujuan akhir dalam meningkatkan kemampuan berpikir. Kemampuan berpikir tingkat tinggi ini menghendaki seseorang untuk menerapkan informasi baru atau pengetahuan sebelumnya dan memanipulasi informasi untuk menjangkau kemungkinan jawaban dalam situasi yang baru (Heong et al, 2011). $\begin{array}{lll}\text { Berfikir tingkat tinggi mencakup } & \text { reflektif, } \\ \text { pemikiran kritis, logis, } & \text { refle }\end{array}$ metakognitif, dan kreatif. Kemampuan berfikir ini dapat diaktivasi ketika siswa dapat menyelesaikan permasalahan, ketidakpastian, pertanyaan-pertanyaan, atau dilemma (King, Goodson \& Rohani, 2012).

Resnick (dalam Arends, 2008) mendefinisikan Higher Order Thinking sebagai berikut:

1. Higher-order thinking is non algorithmic; that is, the path of action is not fully specified in advance.

2. Higher-order thinking tends to be complex.

3. Higher-order thinking often yields multiple solutions, each with costs and benefits, rather than unique solutions.

4. Higher-order thinking involves nuanced judgment and interpretation.

5. Higher-order thinking is effortful. There is considerable mental work involved in the kinds of elaborations and judgments required.

Dari pendapat Resnick tersebut dapat diketahui bahwa masalah HOT merupakan masalah tidak dapat langsung menggunakan rumus dalam penyelesaiannya, masalah yang kompleks, memiliki banyak solusi, membutuhkan interpretasi serta membutuhkan usaha yang keras dalam mengaitkan untuk mengambil keputusan. Hal ini sejalan dengan Stein \& Lane yang mengemukakan bahwa masalah HOTS yaitu masalah yang membutuhkan pemikiran kompleks, tidak ada algoritma yang jelas untuk menyelesaikannya, sulit diprediksi, biasanya menggunakan pendekatan yang berbeda dengan masalah yang ada atau dengan contoh-contoh yang telah diberikan (dalam Thompson, 2008).

Higher Order Thinking Skills menjadi salah satu prioritas dalam pembelajaran matematika sekolah. Siswa yang memiliki keterampilan berpikir tingkat tinggi dapat membedakan ide atau gagasan secara jelas, berargumen dengan baik, mampu memecahkan masalah, mampu mengkonstruksi penjelasan, mampu berhipotesis dan memahami hal-hal kompleks menjadi lebih jelas. Dalam pembelajaran matematika sekolah yang berorientasi pada keterampilan berpikir 
tingkat tinggi, peserta didik diharapkan mampu menjadi manusia yang berkualitas, yaitu mampu bertahan dan berkembang menghadapi tantangan global saat ini.

Berdasarkan revisi yang dilakukan oleh Anderson \& Krathwohl (2001), dimensi proses berpikir Taksonomi Bloom meliputi (1) mengingat (remember-C1); memahami (understand-C2); mengaplikasikan (apply-C3); menganalisis (analysis-C4); mengevaluasi (evaluate-C5); dan mencipta/mengkreasi (create-CO). Kemampuan yang melibatkan menganalisis, mengevaluasi dan mencipta/mengkreasi inilah yang dinamakan keterampilan berpikir tingkat tinggi atau dikenal dengan istilah Higher Order Thinking Skills.

Pengembangan Higher Order Thinking Skills yang dimiliki oleh siswa khususnya dalam matematika tentu bukanlah sebuah hal yang instan. Higher Order Thinking Skills lahir dari sebuah proses yang berkesinambungan dan tidak hanya berorientasi pada hasil. Dibutuhkan suatu proses yang kontinu dan konsisten untuk melatih dan membiasakan para siswa. Oleh karena itu, seorang guru sebagai salah satu pemegang peran penting dalam kegiatan pembelajaran harus dapat memfasilitasi siswa untuk menjadi pemikir dan pemecah masalah yang baik. Proses pembelajaran yang diterapkan harus dapat menjadi wadah bagi siswa untuk mengembangkan keterampilan berpikirnya. Selain itu, sebagai bahan evaluasi terhadap pengetahuan yang telah dimiliki setiap siswa, seorang guru harus menyediakan masalah yang memungkinkan siswa menggunakan keterampilan berfikir tingkat tingginya. Strategi-strategi dan inovasi ini sejalan dengan pendapat Turmudi (2012) yang menyatakan bahwa inovasi dalam pembelajaran matematika cenderung berkaitan dengan tiga hal yaitu bagaimana memahami matematika, bagaimana mengajar matematika dan bagaimana menilai pemahaman matematika.

\section{Higher Order Thinking Skills} hendaknya diintegrasikan sejak awal kegiatan pembelajaran berlangsung hingga selesai bahkan hingga proses refleksi dan evaluasi. Seorang guru tidak bisa hanya berkutat pada pengembangan instrument penilaian saja, tanpa inovasi dalam kegiatan pembelajaran. Siswa tidak akan terlatih untuk menggali dan mengemukakan ide-idenya jika kemampuan berfikir tingkat tingginya hanya dinilai pada saat akhir pembelajaran dalam ulangan harian ataupun ujian semester tanpa melibatkannya dalam proses belajar mengajar. Guru sebagai pemegang peranan penting dalam kegiatan belajar mengajar harus mampu merancang hal tersebut.

NCTM (dalam Sumarmo, 2013) menyebutkan bahwa pembelajaran matematika hendaknya mengutamakan pengembangan daya matematis siswa yang meliputi kemampuan menggali, menyusun konjektur dan menalar logis, menyelesaikan soal non-rutin, memecahkan masalah, berkomunikasi secara matematis dan mengaitkan ide matematis dengan kegiatan intelektual lainnya. Langkah awal yang hendaknya dilakukan oleh seorang guru adalah pemilihan model, metode atau teknik pembelajaran yang sesuai dan relevan untuk diterapkan dalam kaitannya dengan pengembangan higher order thinking skills. Pembelajaran yang dirancang hendaknya mencerminkan keterlibatan siswa secara aktif selama proses kegiatan belajar mengajar. Hal ini tentu sejalan dengan konteks yang termuat dalam kurikulum 2013 serta sesuai dengan konsep pembelajaran abad 21. Model-model pembelajaran yang diterapkan hendaknya berprinsip konstruktivisme sehingga aktivitasnya tidak hanya berpusat pada guru namun juga menuntut peran aktif siswa di dalamnya. Siswa mengkonstruksi pemahamannya secara mandiri dengan panduan dan bantuan dari guru. Mereka memanfaatkan pengetahuan yang telah dimiliki sebelumnya serta fenomenafenomena kontekstual yang berada di sekitarnya untuk memahami, menganalisis serta memecahkan masalah-masalah yang disajikan dalam setiap proses pembelajaran. Badjeber \& Fatimah (2015) mengemukakan bahwa proses pembelajaran yang memberi kesempatan kepada siswa mengeksplorasi suatu konsep atau prinsip dalam matematika melalui suatu kegiatan penyelidikan dapat meningkatkan kemampuan koneksi matematis siswa dengan lebih baik daripada pembelajaran konvensional. Hal ini sejalan 
dengan temuan Kasturi, dkk (2015) bahwa hasil belajar siswa yang mendapat pembelajaran problem posing berorientasi HOTS berada pada kategori baik.

Penyusunan perangkat pembelajaran yang mengintegrasikan higher order thinking skills juga memiliki peranan penting. Rancangan Pelaksanaan Pembelajaran yang disusun oleh guru hendaknya memuat indikator, tujuan ataupun aktivitas pembelajaran yang berorientasi higher order thinking skills sehingga dapat menjadi pedoman dalam melakukan kegiatan belajar mengajar di kelas. Contoh indikator pembelajaran yang mengintegrasikan higher order thinking skills dalam pembelajaran matematika di SMP (materi pola bilangan) diantaranya adalah memilih strategi dan aturan yang sesuai untuk memecahkan masalah yang berkaitan dengan pola bilangan. Dalam indicator ini, siswa tidak hanya dituntut untuk memahami dan menerapkan konsep pola bilangan, namun juga harus dapat menganalisis serta menyimpulkan strategi yang tepat sesuai aturan-aturan yang berlaku bahkan tidak menutup kemungkinan bisa menemukan halhal atau solusi baru.

Dalam proses pembelajaran yang dilaksanakan, guru merancang kegiatan yang menantang siswa untuk mampu menganalisis, mengevaluasi dan mencipta. Penyajian suatu konsep baru dalam matematika harus dikreasikan sehingga mendorong siswa secara mandiri yang mengidentifikasinya. Misal dalam pembelajaran tentang definisi lingkaran, guru menyajikan berbagai gambar contoh dan noncontoh lingkaran. Siswa selanjutnya diminta untuk menganalisis karakteristik khusus lingkaran, sehingga dapat menyusun suatu kesimpulan mengenai definisi lingkaran. Selain itu, guru juga dapat memberikan kesempatan kepada siswa untuk mengajukan pertanyaan-pertanyaan yang bersifat open ended untuk melatih kemampuan berfikir kritis berdasarkan masalah yang disajikan. Setiap rumus dan prinsip yang dipelajari hendaknya tidak disajikan secara langsung kepada siswa, namun diarahkan agar siswa dapat memperoleh dan memahami prinsip-prinsip tersebut melalui generalisasi baik secara induktif maupun deduktif. Contohnya dalam pembelajaran tentang luas lingkaran, siswa dapat diarahkan memperoleh rumus luas lingkaran melalui pendekatan luas segi-n secara induktif. Pada bagian akhir pembelajaran, siswa juga dituntun agar dapat merefleksikan seluruh aktivitas pembelajaran yang telah mereka lakukan. Siswa dilatih untuk mengungkap ide-ide mengenai kelebihan, kekurangan, atau hal-hal lain yang mereka temukan dan alami selama proses pembelajaran berlangsung. Hal ini menjadi sarana latihan bagi siswa dalam meningkatkan kemampuan komunikasi serta berfikir kritis.

Guru juga harus dapat mengajukan pertanyaan-pertanyaan yang dapat mengarahkan siswa untuk dapat berfikir tingkat tinggi. Misalkan dalam membantu siswa menyusun konjektur atau memecahkan masalah, guru dapat mengajukan pertanyaan: Apa yang terjadi jika ...? Bagaimana jika tidak?, Apakah kamu dapat melihat suatu pola?, Kemungkinan apa saja yang dapat terjadi?, Dapatkah kamu memperkirakan bilangan atau objek yang akan muncul berikutnya?, Apa perbedaan strategi/metode yang kamu gunakan dengan strategi/metode temanmu?. Siswa juga dituntun agar dapat memanfaatkan pengetahuan-pengetahuan matematis yang diperoleh sebelumnya serta aplikasinya melalui pertanyaan-pertanyaan: Apa keterkaitan konsep ini dengan konsep ...?, Konsep atau materi apa yang telah kita pelajari sebelumnya yang dapat digunakan untuk memecahkan masalah ini?, Apakah kita pernah memecahkan masalah seperti ini sebelumnya?, Berikan suatu contoh tentang ... dalam kehidupan sehari-hari?. Pertanyaan-pertanyaan ini dapat melatih siswa untuk bernalar, berfikir kritis dan kreatif, serta memahami kebermaknaan pengetahuan matematika yang dipelajari sehingga dapat mendorong peningkatan motivasi belajar mereka.

Selain membiasakan siswa dalam mengembangkan higher order thinking skills pada saat aktivitas pembelajaran, instrumen penilaian yang digunakan juga harus mengakomodir hal tersebut. Dalam setiap evaluasi atau tes yang dilakukan, hendaknya guru selalu memuat soal-soal yang menuntut kemampuan menganalisis, mengevaluasi dan 
mencipta. Beberapa contoh soal matematika SMP yang dapat mengukur kemampuankemampuan tersebut adalah sebagai berikut:

1. Di kota Palu terdapat dua perusahaan Taksi yaitu Taksi Mandiri dan Taksi Utama. Taksi Mandiri menetapkan ketentuan bahwa tarif awal penggunaannya Rp6.000,00 dan tarif setiap kilometer Rp4.000,00. Sedangkan Taksi Utama menetapkan tarif awalnya Rp9.250,00 dan Rp3.500,00 untuk setiap kilometer. Pada jarak tempuh berapakah tarif Taksi Mandiri sama dengan tarif Taksi Utama ? Jelaskan. (Level C4 Menganalisis)

2. Perhatikan gambar trapesium $A B C F$ dan layang-layang $E F C D$ berikut. Diketahui bahwa panjang $C E=21 \mathrm{~cm}$ dan $O C=15$ $\mathrm{cm}$. Tuliskan cara menemukan luas bangun $A B C D E F$. Adakah cara lain untuk menemukan luas bangun $A B C D E F$ tersebut? Jika ada, jelaskan bagaimana cara menentukan luas bangun $A B C D E F$ ? (Level C4 - Menganalisis)

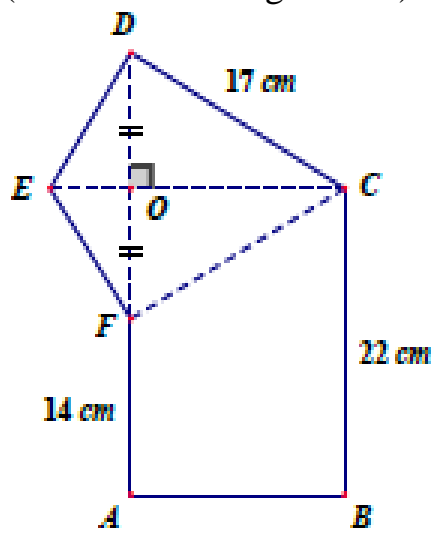

3. Perhatikan gambar di bawah.

Dari gambar tersebut, temukan sekurangkurangnya dua jajar genjang yang luasnya sama dengan jajargenjang $B H D C$, kemukakan alasannya. (Level C4 Menganalisis)

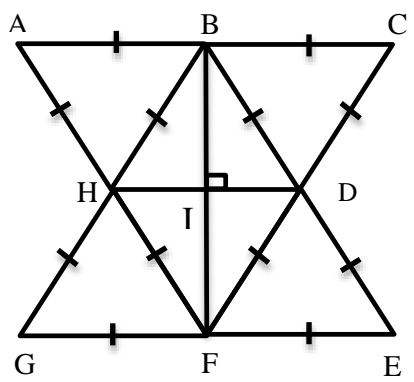

4. Grafik berikut ini menunjukkan biaya sewa 3 mobil A, B dan C.

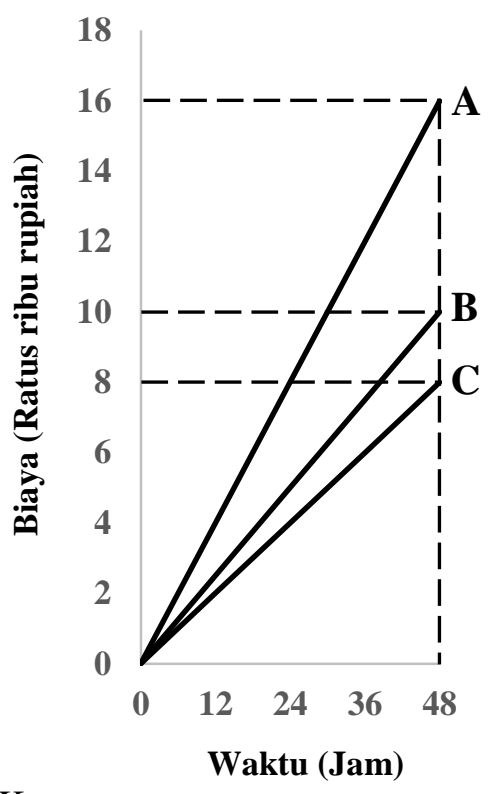

Keterangan

Kapasitas Penumpang

Mobil A : 12 orang

Mobil B : 8 orang

Mobil C : 4 orang

Mobil manakah yang memiliki biaya sewa termurah ? Jelaskan. (Level C5 Mengevaluasi)

5. Buatlah suatu relasi tentang benda-benda dalam kehidupan sehari-hari (misal rumah, sekolah, manusia, dll) yang merupakan fungsi dan nyatakan rumus fungsinya. Berilah penjelasan rumus fungsi yang kalian gunakan. (Level C6 Mencipta)

6. Suatu hari, sekolahmu mengadakan lomba insinyur cilik, dimana setiap anak diminta untuk membuat denah ruangan dalam sebuah rumah impian pada tanah yang berbentuk persegi panjang. Manfaatkan bangun datar segitiga dan segiempat yang telah kamu pelajari untuk mendesain denah ruangan dalam rumah impianmu. Buatlah denah ruangan tersebut "sekreatif dan seartistik" mungkin sehingga tidak sama dengan denah ruangan rumah yang lain dengan menentukan sendiri ukuran sisi-sisi bangun datar yang digunakan (dalam meter)! Kemudian, hitunglah luas dan keliling rumah impian rancanganmu tersebut! (Level C6 - Mencipta) 


\section{KESIMPULAN}

Pengembangan Higher Order

Thinking Skills (HOTS) dalam pembelajaran merupakan salah satu wujud pengimplementasian kurikulum 2013, sehingga kegiatan pembelajaran maupun evaluasi yang dilakukan hendaknya berorientasi pada HOTS. Proses pembelajaran yang diterapkan harus dapat menjadi wadah bagi siswa untuk mengembangkan keterampilan berpikirnya. Selain itu, sebagai bahan evaluasi terhadap pengetahuan yang telah dimiliki setiap siswa, seorang guru harus menyediakan masalah yang memungkinkan siswa menggunakan keterampilan berfikir tingkat tingginya. Seorang guru tidak bisa hanya berkutat pada pengembangan instrument penilaian saja, tanpa inovasi dalam kegiatan pembelajaran

\section{DAFTAR PUSTAKA}

Anderson, L. \& Krathwohl, D. (2001). A Taxonomy For Learning, Teaching and Assessing. New York: Longman.

Badjeber, R \& Fatimah, S. (2015). Peningkatan kemampuan koneksi matematis siswa SMP melalui pembelajaran inkuiri model alberta. Jurnal Pengajaran MIPA, 20(1), 1826.

Heong, Y.et al. (2011). The Level of Marzano Higher Order Thinking Skills among Technical Education Students. International Journal of Social and humanity, 1(2), 121-125.

Kasturi, dkk. (2015). Pengembangan perangkat pembelajaran problem posing berorientasi penerapan HOTS pada materi kesebangunan kelas IX. Jurnal Pancaran Pendidikan, 4(1), 1132.

Kemdikbud. (2016). Peringkat dan Capaian PISA Indonesia Mengalami Peningkatan. (Online), (https://www.kemdikbud.go.id/main/b $\underline{\log / 2016 / 12 / \text { peringkat-dan-capaian- }}$ pisa-indonesia-mengalamipeningkatan), diakses 1 Oktober 2018.

Kemdikbud. (2018). Konferensi Pers UN 2018 Jenjang SMP. (Online), (https://kemdikbud.go.id/main/files/do wnload/9c7fdf36a39328d), diakses 1 Oktober 2018.

King, F., Goodson, L., \& Rohani, F. (2012). Higher Order Thinking Skills. Center for Advancement of Learning and Assessment

Mullis, et al. (2012). TIMMS 2011 International Results in Mathematics. Boston: TIMSS \& PIRLS International Study Center.

OECD. (2016). PISA 2015 Result in Focus. Paris: OECD Publishing.

Purbaningrum, A. K. (2017). Kemampuan berpikir tingkat tinggi siswa SMP dalam pemecahan masalah matematika ditinjau dari gaya belajar. Jurnal Penelitian dan Pembelajaran Matematika, 10(2), 40-49.

Purwanigrum, J. P. (2012). Penerapan Model Wallas untuk Mengidentifikasi Proses Berpikir Kreatif dalam Pengajuan Masalah Matematika Peserta Didik Kelas XI IPA Materi Pokok Fungsi Komposisi. Prosiding Seminar Nasional Matematika VI. Jurusan Pendidikan Matematika, FMIPA UNNES, 233- 240.

Sumarmo. (2013). Kumpulan makalah berpikir dan disposisi matematika serta pembelajarannya. Bandung : Jurusan Pendidikan Matematika FMIPA UPI.

Thompson, T. (2008). An Analysis of Higher Order Thinking on Algebra I End-of Course Tests. (Online), (https://www.researchgate.net/profile/ Tony_Thompson3/ANALYSIS-OFHIGHER-ORDER-THINKING-AnAnalysis-of-Higher-Order-Thinking- 
Rafiq Badjeber, Jayanti Putri Purwaningrum

on-Algebra-I-End-of-Course-

Tests.pdf), diakses 3 Oktober 2018.

Turmudi. (2012). Teachers' perception toward mathematics teaching innovation in Indonesian Junior High School: an exploratory factor analysis. Journal of Mathematics Education, 5(1), 97-120. 